\title{
Morphological and Structural Diversity of Native Mycorrhizae Communities Associated with Gossypium hirsutum L. under Sudano-Sahelian Climate of North Cameroon
}

\author{
Koulagna Issa Honoré ${ }^{1}$, \\ Tchuenteu Tatchum Lucien ${ }^{1}$, Kosma Philippe ${ }^{2}$, \\ Abakar Abba Said ${ }^{1}$, Ismael Ramza Haman ${ }^{1}$, Megueni Clautilde ${ }^{1}$
}

${ }^{1}$ Department of Biological Sciences, Faculty of Sciences, University of Ngaoundere Cameroon
${ }^{2}$ National Advanced School of Engineering, University of Maroua Cameroon

\begin{abstract}
This study describes endomycorrhiza that enter into association with Gossypium hirsitum L. (cotton) grown in North Cameroon. During the study, twenty seven (27) soil samples were collected from three Divisions of the North Cameroon (Benoue, Mayo-Rey, Mayo-Louti). In each Division, nine (09) composite soils were sampled, thus 03 per locality (village), corresponding to sampling sites. Cotton seeds were grown in field for 04 months. Mycorrhizal parameters, spores density and specific richness were determined following to the appropriate methods. After spore extraction, species description and characterization were obtained through the informations provided by the International Vesicular Mycorrhizal fungi collection (INVAM): http://invam.caf.wv.edu/fungi/taxonomy/species ID.htm. Results indicate that mycorrhizal parameters varied depending on sampling sites significantly $(\mathrm{p}<0.05)$. Mayo-Louti $(286.22 \pm 11.47$ spores/100 $\mathrm{g}$ of soil $)$ and Benoue $(273.77 \pm 83.28$ spores/100 $\mathrm{g}$ of soil) had higher spores densities than Mayo-Rey $(209.55 \pm 40.01$ spores/100 $\mathrm{g}$ of soil). The morphological and structural characterization enabled the description of five endomycorrhizal species, belonging to four genera: Glomus constrictum, Glomus manihotis, Acaulospora kentinensis, Entrophospora infrequens, Rhizophagus intraradices. . Glomus is the only genus found in all sampling sites. These findings open opportunities for domestication and application of endomycorrhiza for a sustainable field productivity of cotton in the North Cameroon.
\end{abstract}

Keyswords: North Cameroon, Gossypium Hirsitum, Mycorrhizal Parameters, Spores Density, Specific Richness

\section{Introduction}

North Cameroon region are located in the SudanoSahelian zone, known for the severity of their climatic conditions (Tsozue et al., 2015) and the low level of their soils fertility (Guibert et al., 2008). Several works have shown that the potential contribution of Arbuscular Mycorrhizal Fungi (AMF) to soil can be critical in addressing this type of problems. In poor soils, several plant species are ecologically dependent on mycorrhizal fungi (Gemma et al., 2002). These fungi are a major component of the soil microbial community that have successfully established a symbiotic relationship with two-thirds of plant species (Dechamplain, 2002; Dalpé, 2005; Wang and Qui, 2006). Mycorrhizal fungi allow plants to obtain an extension of its root system (Hamel, 1996) and to optimize its supply in water and mineral elements, to improve its resistance against stresses including cold and drought (Dalpé, 2003). The benefit effect of this symbiosis is not limited to both partners, but also relates to ecosystem integrity since it improves soil quality (Caravaca et al., 2002). In the Northern Cameroon, cotton is a crop of choice, this plant is the engine of economy in Soudano-Sahelian zone of this country (Abakar et al., 2019).

Gossypium hirsutum L. (cotton) is subtropical, perennial plant belong to family Malvaceae, with 50 wild and cultivated species. Seeds produced by cotton plant are used for a multiproduct base like hulls oil, lint and food for animal as well as in textile manufacturing (Aragao et al., 2005). Its leaves and roots are used in medicine; seeds cake is 
used for livestock nutrition and for soil fertilization (Shahin et al., 2018). In Cameroon: the cotton sector employs more than 2500 people and supports more than 2 million people (MINADER, 2013); cotton crop covers about 250000 ha and it is practiced by about 300000 farmers. Average area per producer is around 0.8 ha (Ekorong, 2004 cited by Olina et al., 2008); also, it contributes to rehabilitation of approximately $9.000 \mathrm{~km}$ of tracks, the granting of credits for foodstuff inputs (about 3 billion FCFA/year) and for livestock development integrated in the farm (30-50 million FCFA/year) (Kadekoy-Tigague et al, 2010).

Recent work on cotton aims to improve durably it growth potential. In this respect, the study of the endomycorrhizal status associated to this plant can obviously be of great importance. Furthermore, ecological studies on the diversity of AMF elsewhere, whether they relate to the morphological characterization of spores, molecular biology techniques or endomycorrhizal inoculants tests in the field have been generally limited to exotic species, with little or no investigations on available indigenous species (Symanczik, 2016; Abakar et al., 2019). To the best of our knowledge, no work has been carried out on endogenous mycorrhizal associated with cotton in Cameroon. In this context, the main objective of current study was to determine cotton mycorrhizal status in our country. Specifically it consisted to: (1) Carry out soils physicochemical properties from cotton rhizosphere in the North Cameroon; (2) Evaluate the parameters of cotton root mycorrhizal colonization; (3) Study the diversity of mycorrhizal fungi associated with cotton rhizosphere in the North Cameroon. The interest and usefulness of this work was that the endogenous strains of mycorrhizal fungi associated with cotton rhizosphere will constitute a basic data for the formulation of suitable mycorrhizal inoculum for cotton productivity. Thus, our next work will be focused on the study of effects of endogenous strains of mycorrhizal fungi relative to cotton productivity.

\section{Materials and Methods}

3.1. Physical description of the study sites :

The experiment was conducted in North Cameroon located in agroecological zone I (Sudano sahelian type). Figure 1 illustrates the map showing the study area and the sampling localities.

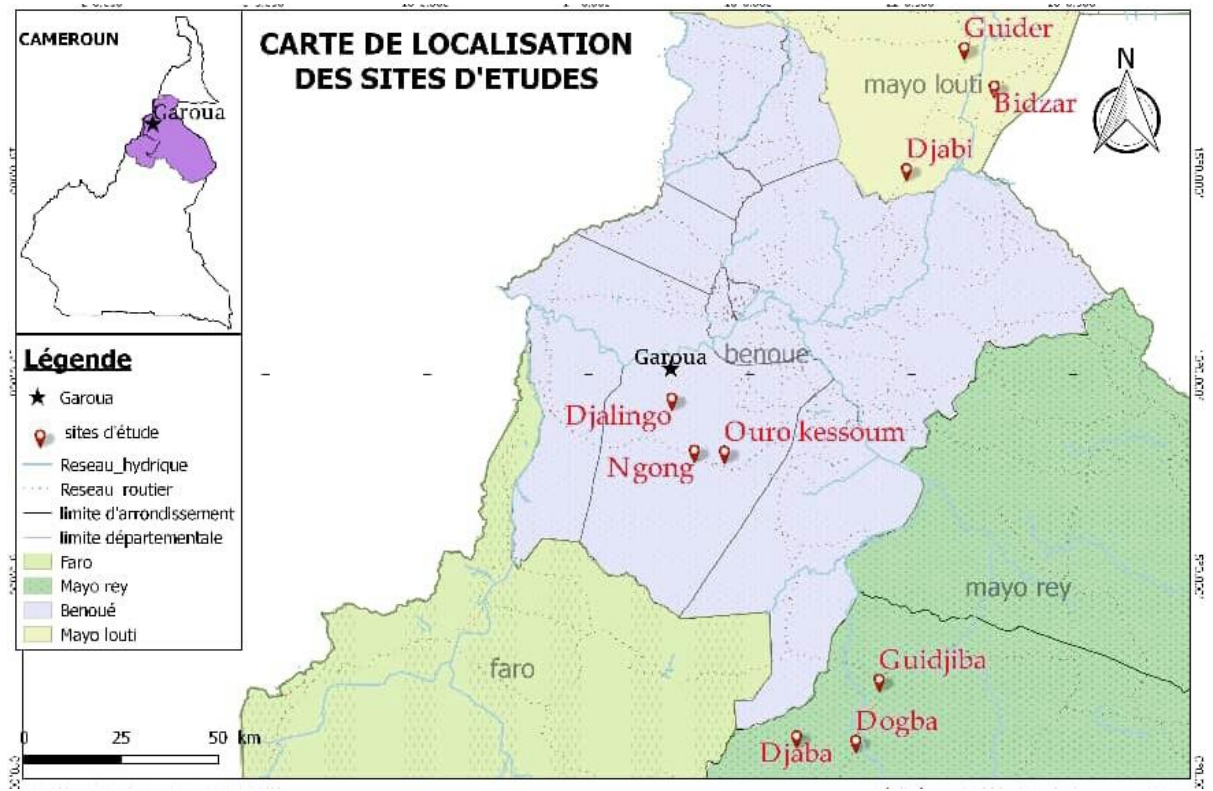

Figure 1. Map of North Cameroon and sampling sites Sampling sites are in red color

\subsection{Soil sampling :}

Soils were sampled at $25 \mathrm{~cm}$ depth (INRA, 2017) after the surface was cleared from plant debris and other large particles. Sampling was carried out in three villages (localities) in each of the three Divisions of our study area as summarized in table 1. 
Table 1. Description of soil sampling sites

\begin{tabular}{|c|c|c|c|c|c|}
\hline Region & Divisions & Localities & Altitude (m) & Longitude $\left({ }^{\circ}\right)$ & Latitude $\left(^{\circ}\right)$ \\
\hline \multirow{9}{*}{$\begin{array}{c}\text { North } \\
\text { Cameroon }\end{array}$} & \multirow{3}{*}{ Benoue } & Djalingo & 244 & $13^{\circ} 27^{\prime} 08^{\prime \prime} \mathrm{E}$ & $9^{\circ} 12^{\prime} 45^{\prime \prime} \mathrm{N}$ \\
\hline & & Ngong & 320 & $13^{\circ} 30^{\prime} 31^{\prime \prime} \mathrm{E}$ & $9^{\circ} 00^{\prime} 05^{\prime \prime} \mathrm{N}$ \\
\hline & & Ouro-Kessoum & 241 & $13^{\circ} 37^{\prime} 35^{\prime \prime} \mathrm{E}$ & $9^{\circ} 00^{\prime} 27^{\prime \prime} \mathrm{N}$ \\
\hline & \multirow{3}{*}{ Mayo-Louti } & Bidzar & 394 & $14^{\circ} 07^{\prime} 48^{\prime \prime} \mathrm{E}$ & $9^{\circ} 55^{\prime} 23^{\prime \prime} \mathrm{N}$ \\
\hline & & Djabi & 268 & $13^{\circ} 48^{\prime} 40^{\prime \prime} \mathrm{E}$ & $9^{\circ} 37^{\prime} 23^{\prime \prime} \mathrm{N}$ \\
\hline & & Guider & 401 & $13^{\circ} 56^{\prime} 36^{\prime \prime} \mathrm{E}$ & $9^{\circ} 55^{\prime} 32^{\prime \prime} \mathrm{N}$ \\
\hline & \multirow{3}{*}{ Mayo-Rey } & Djaba & 387 & $13^{\circ} 54^{\prime} 51^{\prime \prime} \mathrm{E}$ & $8^{\circ} 34^{\prime} 51^{\prime \prime} \mathrm{N}$ \\
\hline & & Dogba & 398 & $13^{\circ} 68^{\prime} 08^{\prime \prime} \mathrm{E}$ & $8^{\circ} 33^{\prime} 48^{\prime \prime} \mathrm{N}$ \\
\hline & & Guidjiba & 393 & $13.73^{\prime} 56^{\prime \prime} \mathrm{E}$ & $8^{\circ} 47^{\prime} 63^{\prime \prime} \mathrm{N}$ \\
\hline
\end{tabular}

\subsection{Determination of the physico-chemical properties of soils}

Soil samples were taken according to the Zig-zag method of Barker (1985). The soils were analyzed at the Laboratory of Soil Analysis and Environmental Chemistry Research Unit of the University of Dschang (Cameroon). Soils physicochemical properties (granulometry, $\mathrm{pH}$, cation exchange capacity, soil contents in nutrients elements such as nitrogen, phosphorus and potassium) were evaluated according to standard methods.

\subsection{Trapping of endomycorrhizal spores from collected soil samples}

Trapping of spore was carried out according to the method described by Brundrett et al., (1996) modified as follows: Gossypium hirsutum was sown in the field in each locality. IRMA Q302 variety was used. Cotton crop were left at natural watering rainfall capacity for four months (may to august 2018) (figure 2). The roots of plants at flowering and rhizospheric soils were sampled for laboratory analysis. The roots in particular were preserved in the refrigerator at $4^{\circ} \mathrm{C}$. Fine harvested cotton roots were thinned according to Phillips and Hayman (1970) method to highlight endomycorrhizal infestation structures. Cotton roots were: (1) carefully washed, the youngest taken and cut to 1-2 $\mathrm{cm}$ in length; (2) put into a test tube with $10 \%$ potassium hydroxide, and heated in a water bath at $90{ }^{\circ} \mathrm{C}$ for 30 minutes to clear the roots; (3) the potash was discarded, filtered through a sieve, before neutralization by rinsing with acidified water; (4) neutralized roots were dept into cotton blue in a water bath for 15 minutes, filtered again through a sieve, and rinsed with distilled water; (5) some of these roots were mounted in water for direct observations, while other were mounted in glycerine for later observations. The mycorrhizal parameters such as mycorrhizal frequency, mycorrhizal intensity, cotton roots arbuscular content were determinated according to Trouvelot et al. (1986). These mycorrhizal parameters were calculated automatically using "Mycocalc" software.

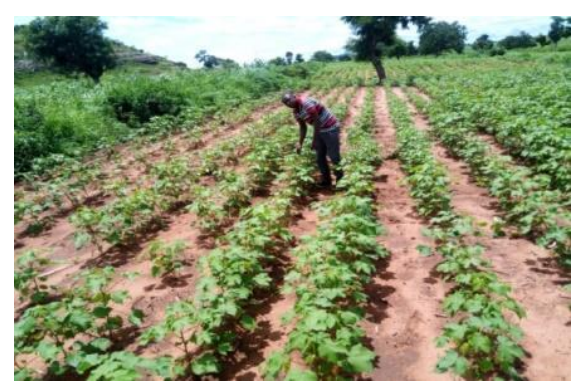

Figure 2 : Cotton plants in Djalingo locality at 40 days after sowing

\subsection{Extraction of endomycorrhizal spores from} the rhizospheric Gossypium hirsitum soils

Endomycorrhizal spores were extracted according to the wet extraction method described by Gerdemenn and Nicolson (1963) modified by the follows steps: (a) suspension of soil sample (100 g) in water; (b) mechanical stirring of soil for $15 \mathrm{~min}$ (repeated thrice); (c) passing the soil through a series of sieves of size corresponding to the range of spores sizes of between [25 - $400 \mu \mathrm{m}[$; (d) creating a density gradient by centrifugation; (e) filtering through a $25 \mu \mathrm{m}$ sieve for spores collection.

\subsection{Morphological and structural characterization of endomycorhizal spores in cotton root}

For the identification of Arbuscular Mycorrhizal Fungi (AMF), the extracted spores were grouped by morphotype under criteria such as size, shape and color. Two groups of spores from each morphotype were mounted between slide and coverslip, thus one in PVGL (Polyvinyl-Lactic Acid-Glycerol), and the other in the PVGL-Melzer Reagent mixture $(1: 1 / \mathrm{v}: \mathrm{v}) \quad$ (Koske and Tessier, 1983). The morphotypes determination of the genus was made based on the classifications described by Morton and Benny (1990). The original descriptions of species, as well as the descriptions provided on the website of the International Vesicular Mycorrhizal fungi collection (INVAM): http://invam.caf.wv.edu/fungi/ taxonomy/species ID.htm were used as the reference during the identification process. Morphological characters of 
spores were compared with those of standard specimens and the reference strains. Several parameters were used to characterize AMF spores and were evaluated based on the formula proposed by Sghir et al., (2013). The species richness refers to the total number of different morphotypes recorded in a $100 \mathrm{~g}$ soil sample, and was expressed by: $R(\%)=\mathbf{N} / \mathbf{1 0 0} \mathbf{g}$, where $\mathrm{N}$ is the number of different specimens. The specific density indicates the number of spores recovered in $100 \mathrm{~g}$ soil sample, and was express as: $\mathbf{D}(\boldsymbol{\%})=\mathbf{N} / \mathbf{1 0 0} \mathbf{g}$, where $\mathrm{N}$ is the number of spores. The diversity of endomycorrhizal species in all the sites was calculated using Shannon-Weaver diversity index (H) (Shannon, 1948). The Shannon index is given by the formula below: $\mathbf{- H}=\mathbf{- \Sigma} \mathbf{p i} \operatorname{lnpi}$, where $\mathbf{p i}=$ $\mathbf{S} / \mathbf{N}, \mathbf{S}$ is the total number of individuals of one species, $\mathrm{N}$ is the total number of all individuals in the sample and $\ln =$ logarithm to base e. The proportion of species relative to total number of species (pi) was calculated, and multiplied by natural logarithm of this proportion (ln pi). The results were summed across the species, and multiplied by -1 .

\subsection{Data analysis}

Data were subjected to variance analysis followed by the Duncan multiple range tests when any significant effect was observed. The statistical software "Statgraphics plus" was used for this propose. Excel 2010 software was used for data entry and graphing.

\section{Results and discussion}

\subsection{Physicochemical} composite soils of the sampling sites

Composite soil samples from different Division of the North Cameroon had varying physicochemical properties (Table 2). The Granulometry study shown that the most sandy soils was from Benoue $(75 \pm 10.44 \%)$, while the highest soil clay contents was recorded in Mayo-Louti $(17.66 \pm 15,88 \%)$ and the soils of Mayo-Rey have the highest silt content $(28.00 \pm 10.78 \%)$. Soil $\mathrm{pH}$ varied from $4.30 \pm 0.20$ to $7.82 \pm 0.00$, respectively for Ngong in Benoue Division and Djaba in Mayo-Rey Division. Globally soil of Benoue Division is acid $(\mathrm{pH}=5.00$ $\pm 0.60)$ while that of Mayo-Rey $(\mathrm{pH}=7.75 \pm 0.06)$ is basic and Mayo-Louti's soil is neutral $(\mathrm{pH}=6.61$ \pm 1.00 ). The lowest soil phosphorus contents was from Mayo Rey and it ranged from $1.77 \pm 0.06 \mathrm{ppm}$ to $3.02 \pm 0.02 \mathrm{ppm}$, respectively for Djaba and Dogba localities. Soils from Benoue and MayoLouti have presented the highest phosphorus contents and it ranged from $7.21 \pm 0.32 \mathrm{ppm}$ to $20.38 \pm 0.28$ respectively for Bidzar and Guider localities. However, soil of Ngong in the Benoue Division had a phosphorus content almost twice lower $(4.53 \pm 0.12)$ compared to those of other localities of this Division. Globally, soil of Mayo-
Louti had a phosphorus content (13.65 $\pm 6.58 \mathrm{ppm})$ almost twice as high as Benoue soil $(6.95 \pm 2.12$ ppm) and almost six fold higher than that of MayoRey Division $(2.41 \pm 0.62 \mathrm{ppm})$. Regarding soils nitrogen contents, the highest values of this parameter are found in Mayo-Louti $(0.55 \pm 0.32$ $\mathrm{g} / \mathrm{kg}$ ) while the lowest was observed in Mayo-Rey $(0.31 \pm 0.04 \mathrm{~g} / \mathrm{kg})$. Soil potassium content is higher in Mayo-Rey $(0.32 \pm 0.05 \mathrm{meq} / 100 \mathrm{~g}$ of DM) while the lowest value was observed in Benoue $(0.20 \pm$ $0.10 \mathrm{meq} / 100 \mathrm{~g})$. The soils of North Cameroon was low in organic matter: soil carbon content ranged from $0.46 \pm 0.1 \%$ to $1.94 \pm 0.17 \%$ and organic matter content ranged from $0.8 \pm 0.1 \%$ to $3.34 \pm$ $0.43 \%$ respectively for Djaba and Bidzar. However these soils had high mineral elements content. Soil phosphorus content varied from $1.77 \pm 0.06$ to $20.38 \pm 0.28 \mathrm{mg} / \mathrm{kg}$ respectively for Djaba in Mayo- Rey and for Guider in Mayo-Louti. It was observed in this study that soil $\mathrm{pH}$ varied from 4.30 \pm 0.20 for Ngong in Benoue Division to $7.82 \pm 0.00$ for Djaba in Mayo-Rey Division, this result corroborate partially data found in litterature.. Indeed, Tobolbai et al. (2018) did studies on the morphological and structural diversity of native endomycorrhizae associated with maize in Northern Cameroon and observed acid soils for Benoue (4.98), Mayo-Louti (5.30) and Mayo-Rey (5.02). Olina et al. (2008) revealed that average soil $\mathrm{pH}$ of Far North Cameroon is 6. In addition Mbonigaba et al. (2009) reported that tropical soils are acidic. In the current study, soil contents in organic matter and mineral elements vary depending on study sites, thus suggesting that these localities would influence mycorrhizal parameters as well as the density and diversity of mycorrhizal fungi associated with plants rhizosphere. Indeed, Shukla et al. (2009) and Voko et al. (2013) reported that the distribution, abundance and viability of endogenous AMF species results from soil physicochemical properties. In addition, several authors (Diouf et al., 2013 ; Tobolbai et al., 2018) indicated that the specific richness of the Arbuscular Mycorrhizal Fungi (AMF) spores increases with the clay. In this respect, Guider locality would present the highest specific richness of AMF spores, but this needs to be investigated. 
Table 2. Soils physico-chemical properties

\begin{tabular}{|c|c|c|c|c|c|c|c|c|c|}
\hline Parameters & \begin{tabular}{|l|} 
Djalingo \\
\end{tabular} & \begin{tabular}{|l|} 
Ngong \\
\end{tabular} & Ouro-Kessoum & Bidzar & Djabi & Guider & Djaba & Dogba & Guidjiba \\
\hline $\mathrm{pH}$ & $5.40 \pm 0.26^{\mathrm{bc}}$ & $4.30 \pm 0.20^{\mathrm{s}}$ & $5.30 \pm 0.10^{\mathrm{b}}$ & $6.60 \pm 0.36^{\mathrm{d}}$ & $5.70 \pm 0.34 \mathrm{c}$ & $7.71 \pm 0.00^{\mathrm{z}}$ & $7.82 \pm 0.00^{\mathrm{e}}$ & $7.69 \pm 0.04^{\mathrm{e}}$ & $7.76 \pm 0.05^{\mathrm{e}}$ \\
\hline $\mathrm{N}(\mathrm{g} / \mathrm{kg})$ & $0.28 \pm 0.07^{\mathrm{ab}}$ & $0.36 \pm 0.12^{\mathrm{d}}$ & $0.29 \pm 0.02^{\mathrm{abc}}$ & $0.88 \pm 0.32^{\mathrm{f}}$ & $0.53 \pm 0.16^{\mathrm{e}}$ & $0.24 \pm 0.28^{\mathrm{a}}$ & $0.31 \pm 0.06^{\text {bed }}$ & $0.50 \pm 0.02^{\mathrm{e}}$ & $0.35 \pm 0.45^{\text {cd }}$ \\
\hline $\mathrm{P}(\mathrm{ppm})$ & $7.82 \pm 0.07^{\mathrm{f}}$ & $4.53 \pm 0.12^{\mathrm{d}}$ & $8.51 \pm 0.02 \mathrm{~g}$ & $7.21 \pm 0.32^{\mathrm{e}}$ & $13.36 \pm 0.16^{\mathrm{h}}$ & $20.38 \pm 00.28^{i}$ & $1.77 \pm 0.06^{\mathrm{a}}$ & $3.02 \pm 0.02^{\mathrm{c}}$ & $2.44 \pm 0.45^{\mathrm{b}}$ \\
\hline $\mathrm{Ca}($ méq $/ 100 \mathrm{~g})$ & $17.50 \pm 1.35^{\mathrm{a}}$ & $36.2 \pm 6.00^{\mathrm{bcd}}$ & $21.30 \pm 2.23^{\mathrm{a}}$ & $43.70 \pm 4.61^{\mathrm{d}}$ & $31.50 \pm 0.62^{b}$ & $35.36 \pm 1.13^{\mathrm{bc}}$ & $17.68 \pm 1.20^{\mathrm{a}}$ & $65.58 \pm 10.00^{\mathrm{e}}$ & $42.16 \pm 3.17^{\mathrm{cd}}$ \\
\hline $\mathrm{Mg}(\mathrm{mg} / 100 \mathrm{~g})$ & $101.30 \pm 2.45^{\mathrm{b}}$ & $180.00 \pm 12.50^{\mathrm{d}}$ & $165.00 \pm 20.00^{\mathrm{d}}$ & $127.10 \pm 7.21^{\circ}$ & $135.00 \pm 7.00^{\circ}$ & $107.44 \pm 6.23^{b}$ & $46.24 \pm 4.71^{\mathrm{a}}$ & $35.36 \pm 2.35^{\mathrm{a}}$ & $44.88 \pm 4.08^{\mathrm{a}}$ \\
\hline $\mathrm{K}(\mathrm{meq} / 100 \mathrm{~g})$ & $0.14 \pm 0.02^{\mathrm{a}}$ & \begin{tabular}{|l|}
$0.14 \pm 0.00^{\mathrm{s}}$ \\
\end{tabular} & \begin{tabular}{|l|}
$0.32 \pm 0.03^{\mathrm{c}}$ \\
\end{tabular} & $0.14 \pm 0.01^{\mathrm{s}}$ & $0.32 \pm 0.02^{\mathrm{c}}$ & $0.43 \pm 0.05^{\mathrm{e}}$ & $0.27 \pm 0.01^{\mathrm{b}}$ & $0.32 \pm 0.02^{\circ}$ & $0.38 \pm 0.01^{\mathrm{d}}$ \\
\hline $\mathrm{OM}(\mathrm{mg} / \mathrm{g})$ & $2.05 \pm 0.16^{\mathrm{bc}}$ & $2.91 \pm 0.16^{\mathrm{de}}$ & $2.26 \pm 0.23^{\circ}$ & $3.34 \pm 0.43^{\mathrm{e}}$ & $2.48 \pm 0.10^{\mathrm{cd}}$ & $0.86 \pm 0.13^{\mathrm{a}}$ & $0.80 \pm 0.10^{\mathrm{a}}$ & $1.94 \pm 0.64^{\mathrm{bc}}$ & $1.53 \pm 0.54^{b}$ \\
\hline $\mathrm{OC}(\mathrm{mg} / \mathrm{g})$ & $1.19 \pm 0.13^{\mathrm{bc}}$ & $1.69 \pm 0.37 \mathrm{de}$ & $1.31 \pm 0.26^{\mathrm{c}}$ & $1.94 \pm 0.17^{\mathrm{e}}$ & $1.44 \pm 0.12^{\mathrm{cd}}$ & $0.50 \pm 0.00^{\mathrm{a}}$ & $0.46 \pm 0.10^{\mathrm{s}}$ & $1.13 \pm 0.06^{\mathrm{bc}}$ & $0.89 \pm 0.14^{\mathrm{b}}$ \\
\hline Clay $(\mathrm{g} / 100 \mathrm{~g})$ & $7.00 \pm 0.00^{\mathrm{ab}}$ & $7.00 \pm 0.00^{\mathrm{sb}}$ & $6.00 \pm 0.00^{\mathrm{a}}$ & $8.00 \pm 0.00^{\mathrm{bc}}$ & $9.00 \pm 0.00^{\circ}$ & $36.00 \pm 1.00 \mathrm{~g}$ & $16.00 \pm 2.00^{\mathrm{s}}$ & $18.00 \pm 2.00^{f}$ & $11.00 \pm 1.00^{\mathrm{d}}$ \\
\hline Silt $(\mathrm{g} / 100 \mathrm{~g})$ & $24.00 \pm 0.00^{\mathrm{d}}$ & $6.00 \pm 0.00^{\mathrm{a}}$ & $24.00 \pm 0.00^{\mathrm{d}}$ & $44.00 \pm 0.00^{\mathrm{s}}$ & $12.00 \pm 0.00^{\mathrm{b}}$ & $17.00 \pm 2.00^{\circ}$ & $24.00 \pm 4.00^{\mathrm{d}}$ & $21.00 \pm 3.46^{\mathrm{d}}$ & $41.00 \pm 2.00^{\circ}$ \\
\hline Sand $(\mathrm{g} / 100 \mathrm{~g})$ & $68.00 \pm 0.00^{\mathrm{d}}$ & $87.00 \pm 0.00^{f}$ & $70.00 \pm 0.00^{\mathrm{d}}$ & $48.00 \pm 0.00^{\mathrm{b}}$ & $79.00 \pm 0.00^{\mathrm{a}}$ & $44.67 \pm 3.50^{\mathrm{a}}$ & $58.00 \pm 3.00^{\circ}$ & $58.00 \pm 3.00^{\mathrm{c}}$ & $46.00 \pm 1.00^{\mathrm{sb}}$ \\
\hline $\mathrm{CEC}(\mathrm{mEq} / 100 \mathrm{~g})$ & $5.73 \pm 0.57^{\mathrm{a}}$ & $7.21 \pm 1.66^{\mathrm{sb}}$ & $12.48 \pm 0.79^{\mathrm{c}}$ & $24.74 \pm 4.20^{\text {ef }}$ & $11.12 \pm 2.48^{\mathrm{bc}}$ & $21.45 \pm 1.91^{\mathrm{de}}$ & $23.45 \pm 1.64^{\text {ef }}$ & $27.28 \pm 1.55^{f}$ & $19.15 \pm 4.09^{\mathrm{d}}$ \\
\hline
\end{tabular}

DM : Dry matter ; CEC : Cation Exchange Capacity ; OC : Organic carbon, OM : Organic matter Values of line affected by the same letter are not sigificantly different $(p<0.01)$

\subsection{Mycorrhizal parameters}

Globally, The analysis of variance (ANOVA) revealed that there was a significant incidence $(p<0.05)$ of sampling sites relative to mycorrhizal parameters such as mycorrhizal intensity colonization, roots arbuscular content.

\subsubsection{Mycorrhizal frequency}

Mycorrhizal frequency varied from $16.66 \pm 5.51 \%$ for Bidzar to $25.45 \pm 6.70 \%$ for Djabi in Mayo-Louti Division. In Benoue Division it is higher in Ngong $(36.66 \pm 4.60 \%)$ than in Ouro-kessoum (26.66 \pm $4.03 \%$ ) while in Mayo- Rey Division it varied from $32.66 \pm 5.05 \%$ for Dogba to $34.16 \pm 7.00 \%$ for Guidjiba. Generally, mycorrhizal frequency was higher in Mayo-Rey (34.60 $\pm 0.82 \%)$ and Benoue $(31.10 \pm 5.09 \%)$ than in Mayo-Louti $(21.75 \pm 4.55 \%)$

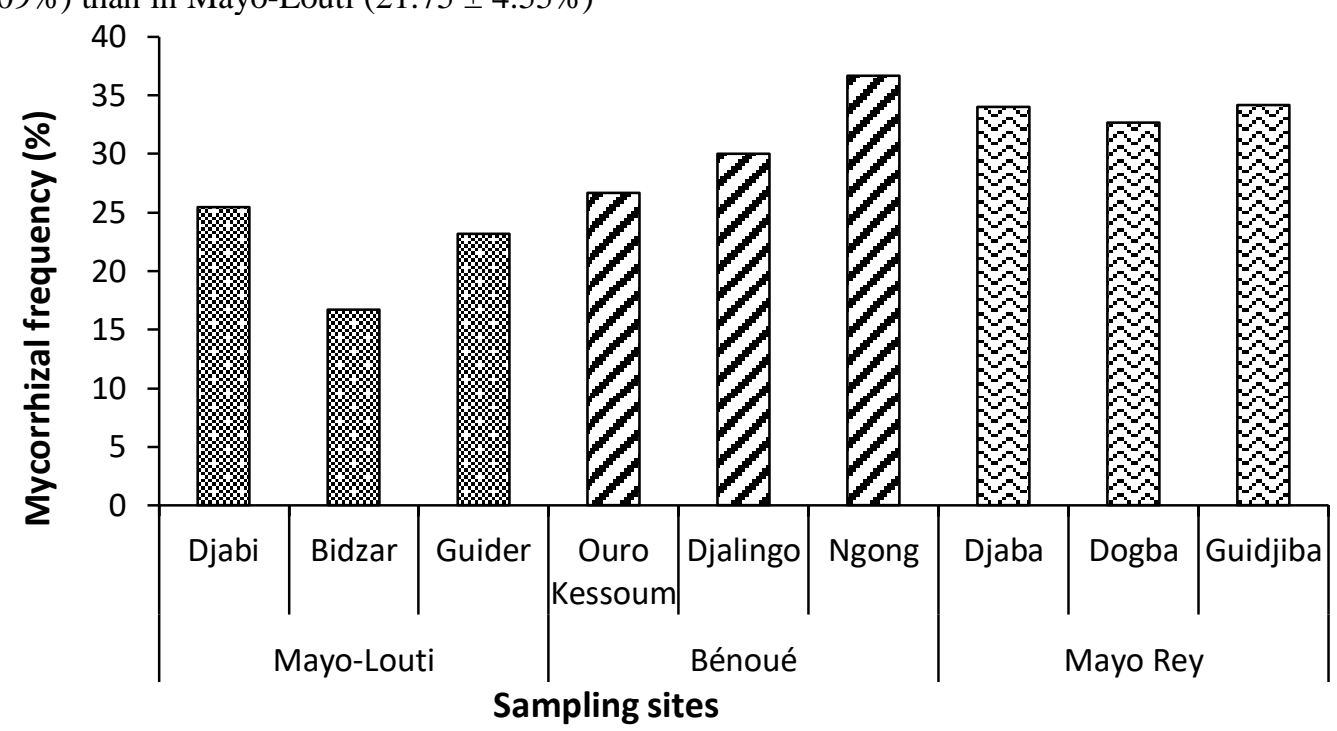

Figure 3: Variation in mycorrhizal frequency depending on sampling sites

\subsubsection{Mycorrhizal intensity colonization}

In Mayo-Louti, the highest mycorrhizal intensity colonization was observed in Djabi $(1.02 \pm 0.88 \%)$ while the smallest value of this parameter was from Bidzar $(0.17 \pm 0.05 \%)$. Guider had presented an intermediate value $(0.7 \pm 0.62 \%)$. In the Benoue Division, cotton mycorrhizal intensity in Ngong was $19.83 \pm 7.57 \%$. Mycorrhizal intensity was almost 04 fold higher than that of Djalingo $(5.33 \pm 2.02 \%)$ and (figure 3). The values of mycorrhizal frequency obtained in the current study are higher than data reported by Tobolbai et al. (2018). These authors reported that roots mycorrhizal frequency of mays was $3.66 \%$ for Benoue, $4.33 \%$ for Mayo-Rey and $4.66 \%$ for Mayo-Louti. The higher value of cotton mycorrhizal frequency compared to that of mays would be justified by that mycorrhizal fungi would have a better association with cotton than maize, but this need to be investigated. The mycorrhizal frequency confirms the existence of a mycorrhizal symbiosis through the number of roots infested by the spores of the arbuscular mycorrhizal fungi and marks the beginning of the symbiotic phase. In this respect, mycorrhizal symbiosis exists with cotton regardless of North Cameroon locality. 
colonization with spores of arbuscular mycorrhizal fungi and provides information about the symbiotic phase evolution. In Northern Cameroon, the cotton roots were all infested with arbuscular mycorrhizal fungi, but this colonization varied depending on sampling sites.

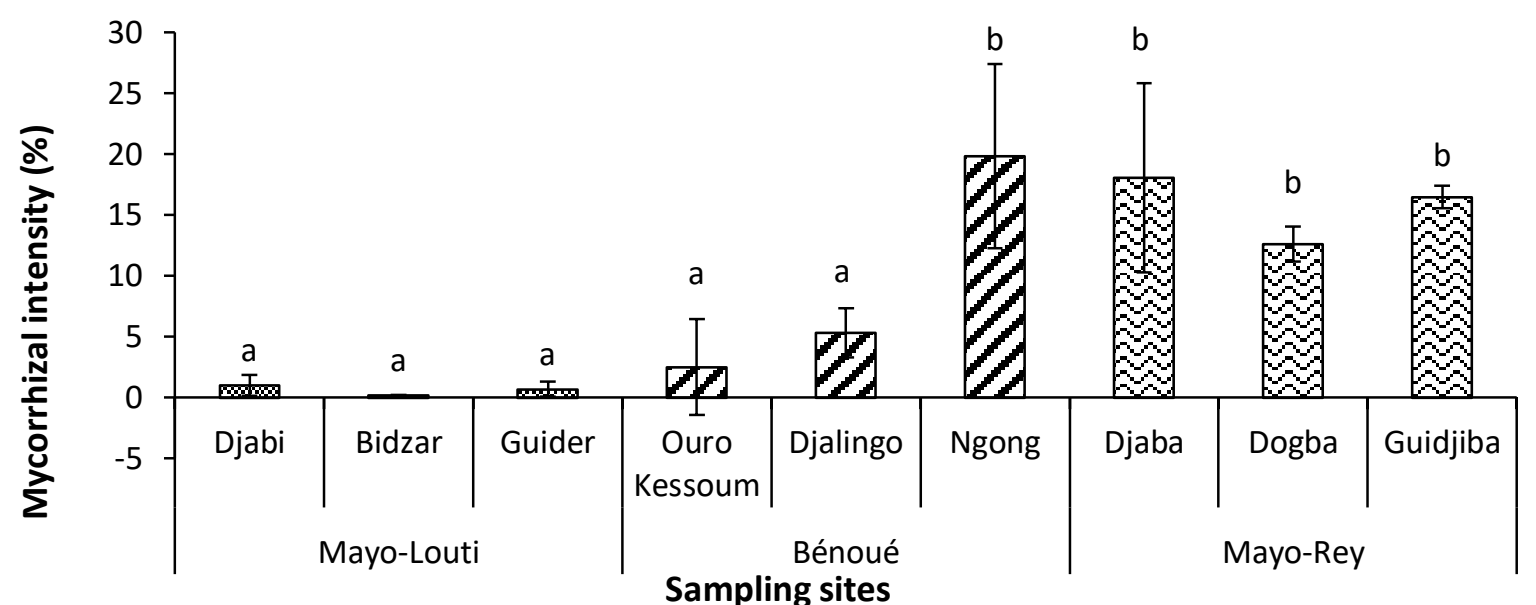

Figure 4: Variation on mycorrhizal intensity of cotton depending on sampling sites

Bars affected by the same letter are not different significantly $(\mathrm{p}<0.05)$ for each Division

\subsubsection{Arbuscular content}

In Mayo-Louti Division, arbuscular content was higher in Djabi locality $(0.5 \pm 0.88 \%)$, followed by Guider $(0.2 \pm 0.75 \%)$ and Bidzar $(0.01 \pm 0.00 \%)$. In Benoue Division, the arbuscular content in Ngong locality $(14.3 \pm 8.21 \%)$ was 12 fold higher than that of Djalingo $(1.2 \pm 1.01 \%)$ and 20 fold higher than that of Ouro-kessoum $(0.64 \pm 1.08 \%)$. In Mayo-Rey Divsion, the arbuscular content was higher in Djaba $(11.37 \pm 7.58 \%)$ and Dogba $(11.12 \pm 1.12 \%)$ localities compared to Guidjiba (10.95 $\pm 2.86 \%)$. Globally, the highest value of arbuscular content $(11.14 \pm 0.21 \%)$ was from Mayo-Rey Division and the smallest value $(0.23 \pm 0.24 \%)$ was from Mayo-
Louti while intermediate value $(5.38 \pm 7.73)$ of this parameter was observed in Benoue (figure 5). Values obtained relative to the roots arbuscular content in the current study are lower than that of Sidhoum (2011), who studied the diversity of arbuscular mycorrhizas associated to olive tree and found that it varied from 12 to $33.67 \%$. The arbuscular content shows the level of mycorrhizal structures differentiation in order to assess the efficiency and type of mycorrhizal symbiosis. There was a positive and significant correlation between mycorrhizal frequency and mycorrhizal intensity ( $\mathrm{r}=0.9$; $\mathrm{P}<0.001)$, mycorrhizal intensity and cotton roots arbuscular content $(\mathrm{r}=0.977 ; \mathrm{P}<0.0001)$.

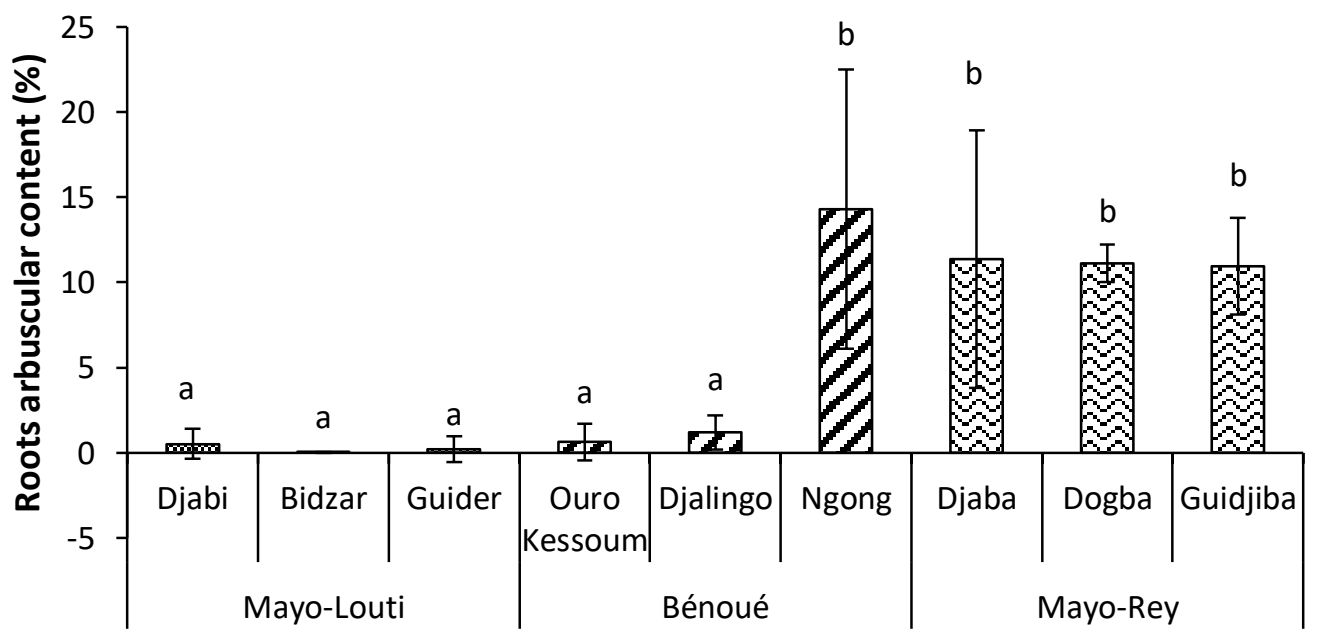

\section{Sampling sites}

Figure 5: Variation of the roots arbuscular content of Gossypium hirsutum (L.) depending on sampling sites Bars affected by the same letter are not different significantly $(\mathrm{p}<0.05)$ for each Division 


\subsection{Spores of mycorrhizal fungi associated with Cotton rhizosphere: Density and identified species}

There was a significant $(\mathrm{p}<0.05)$ difference between the densities of spores associated with cotton rhizosphere relative to localities. However localities did not affect significantly species richness. In MayoLouti Division, the highest densities was observed in Bidzar (295.33 \pm 84.89 spores/100 g) and Djabi $(290.00 \pm 46.50$ spores/100 g) locality and the smallest value was from Guider (273.33 \pm 10.11 spores/100 g). In Benoue Division, spores density in Ouro-Kessoum $(333.66 \pm 93.66$ spores/100 g) is 02 fold higher than that from Djalingo $(178.66 \pm 21,19$ spores/100 g) and 1.08 fold higher than that from Ngong (309.00 \pm 19.28 spores/100 g). In Mayo-Rey Division, Guidjiba locality had the lowest density $(164.00 \pm 84.89$ spores/100 g); it is 1.45 fold lower than that of Djaba $(239.00 \pm 59.80$ spores $/ 100 \mathrm{~g})$ and 1.37 fold lower than that of Dogba (225.66 \pm 67.24 spores/100 g). Globally, Mayo-Louti $(286.22 \pm 11.47$ spores/100 g) and Benoue (273.77 \pm 83.28 spores/100 g) had higher densities than Mayo-Rey (209.55 \pm 40.01 spores $/ 100 \mathrm{~g}$ ). In general, Ouro-kessoum locality in Benoue Division had the highest specific richness and five (05) species of mycorrhizae were identified in this locality. Glomus is the only genus found in all sampling sites. Benoue, Mayo-Rey and Mayo-Louti had respectively 05, 04 and 03 listed species. The values of Shannon index $\left(\mathrm{H}^{\prime}\right)$ of all the localities (Table 3 ) varied between 0.31 for Djalingo to 0.61 for Ouro-kessoum, thus suggesting that all the three Divisions had a very low diversity of AMF spores. However, Pielou's equitability index varied from 0.65 to 0.99 respectively for Djalingo and Ngong localities, thus suggesting that identified species in a locality are fairly distributed. In this study five (05) types of spores distributed in four (04) genrera could be identified (Figure 6): Glomus (2 species), Acaulospora (1 species), Rhizophagus (1 species), Entrophospora (1 species). It was observed in this study that spore densities varied from $164.00 \pm$ 84.89 to $333.66 \pm 93.66$ spores/100g. These values corroborate Zézé et al. (2007) who reported that spores densities ranged from 152.50 to 379.00 spores/100g in different types of forests in Côte
d'Ivoire. In addition, Haougui et al. (2013) found that the average spore's density from four marked gardenning sites in the Maradi region of Niger was 284.8 spores $/ 100 \mathrm{~g}$ of soil. However, Tobolbai et al. (2018) reported that spores density from mays rhizosphere was 532 spores/100 g in Benoue, 304 spores/100g in Mayo-Rey and 121 spores / $100 \mathrm{~g}$ in Mayo-Louti. The pH of soil would affect the dissemination an life cycle of spores of mycorrhizal fungi in each locality. It appears in this study that the highest spore's density values are found in localities which acidic $\mathrm{pH}$ and the lowest were from localities which basic $\mathrm{pH}$ (Table 2), thus corroborate Cius (2017) who reported that acidic or neutral $\mathrm{pH}$ better promotes the multiplication of AMF spores. Spores density allows identifying the soil that is most favorable for the multiplication of AMF spores. After direct counting, the isolation of these spores made it possible to identify and describe them. Results obtained on specific richness partially corroborate Tobolbai et al. (2018) on mays roots in North Cameroon who found that specific richness varied from 2 and 4 species, but these authors did not found both species Acaulospora kentinensis and Entrophospora infrequens in mays rhizosphere. However, Voko et al. (2013) found that specific richness of cassava rhizosphere in Côte d'Ivoire ranged from 20 to 32 species. This would be explained by that AMF are specific to a host plant. In this study the presence of Glomus genus in all sampling sites does not surprise us: soil $\mathrm{pH}$ has an influence on species diversity Bansal et al. (2012), Glomus genus adapts in all soil $\mathrm{pH}$ values with optimum $\mathrm{pH}$ varying from 6 to 8 . In addition, several authors (Azcón-Aguillar, 2003; Mathimaran et al. 2005; Abbas et al., 2006) reported that Glomus genus has a greater geographic distribution in the world especially in the agricultural environment and specifically in the semi-arid zones. In this work, we expected the locality of Guider to have the most specific richness due to its clay-rich soil, but the highest value of this parameter was rather from the soil of Ouro-Kessoum, thus suggesting that the diversity of AMF at different sites was influenced not only by soil clay content, but also by other soil compositions.

Table 3. Diversity and abundance of arbuscular mycorrhizal fungi species depending on sampling sites

\begin{tabular}{|c|c|c|c|c|c|c|c|c|c|c|}
\hline Divisions & Localities & A. kentinensis & E. infrequens & G. constrictum & G. manihotis & R. intraradices & $\mathrm{D}$ & $\mathrm{S}$ & $\mathrm{H}^{\prime}$ & $\mathrm{R}$ \\
\hline \multirow{2}{*}{ Mayo-Louti } & Bidzar & ++ & - & $* * *$ & $* * *$ & - & $295,33 \pm 84,89^{\text {cd }}$ & 3 & 0,42 & 0,88 \\
\hline & Guider & ++ & - & $* * *$ & $* * *$ & - & $273,33 \pm 10,11^{\text {bcd }}$ & 3 & 0,41 & 0,86 \\
\hline \multirow[b]{2}{*}{ Benoue } & Ngong & & +++ & $* * *$ & +++ & +++ & $309,00 \pm 19,28^{\text {cd }}$ & 4 & 0,6 & 0,90 \\
\hline & $\begin{array}{l}\text { Ouro- } \\
\text { Kessoum }\end{array}$ & +++ & ++ & $* * *$ & +++ & + & $333,66 \pm 93,66^{\mathrm{d}}$ & 5 & 0,61 & 0,99 \\
\hline Mayo-Rey & Guidjiba & + & - & +++ & +++ & - & $164,00 \pm 37,72^{\mathrm{a}}$ & 3 & 0,42 & 0,90 \\
\hline
\end{tabular}

-: absent; +: weakly abundant (20); ++: Averagely abundant (21-40); +++: abundant (41-100); ***: highly abundant (> 100) ; D: Spores density; S: species richnes, H': Shannon index; R: Pielou's equitability index.Values of column affected by the same letter are not significantly different $(\mathrm{p}<0.05 \%)$. 
A

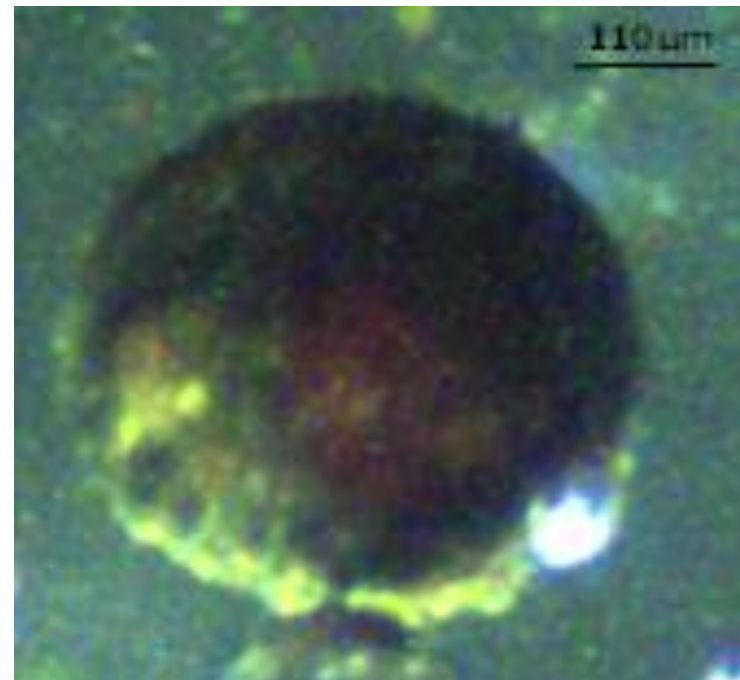

A1

B

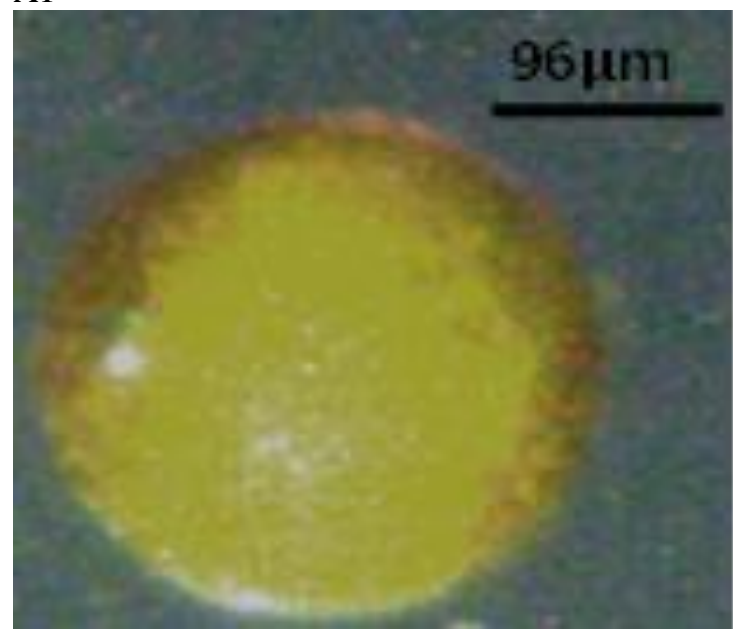

B1

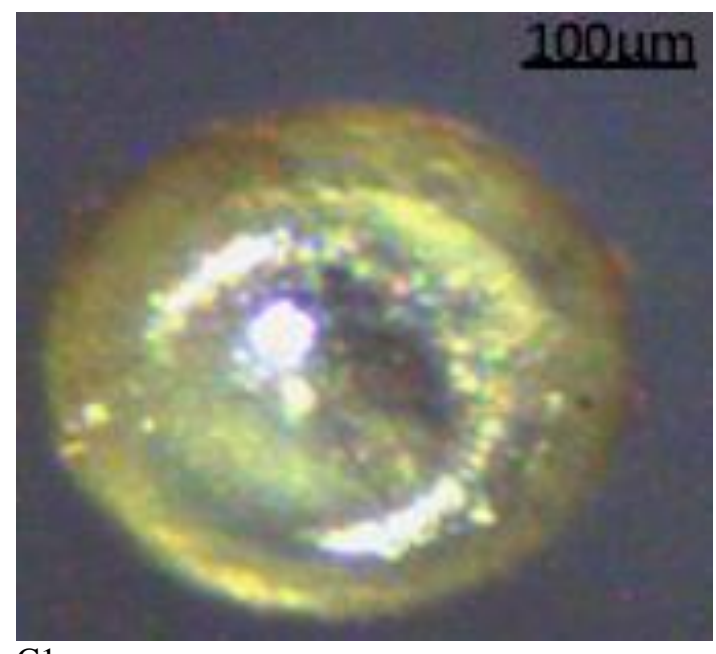

$\mathrm{C}$

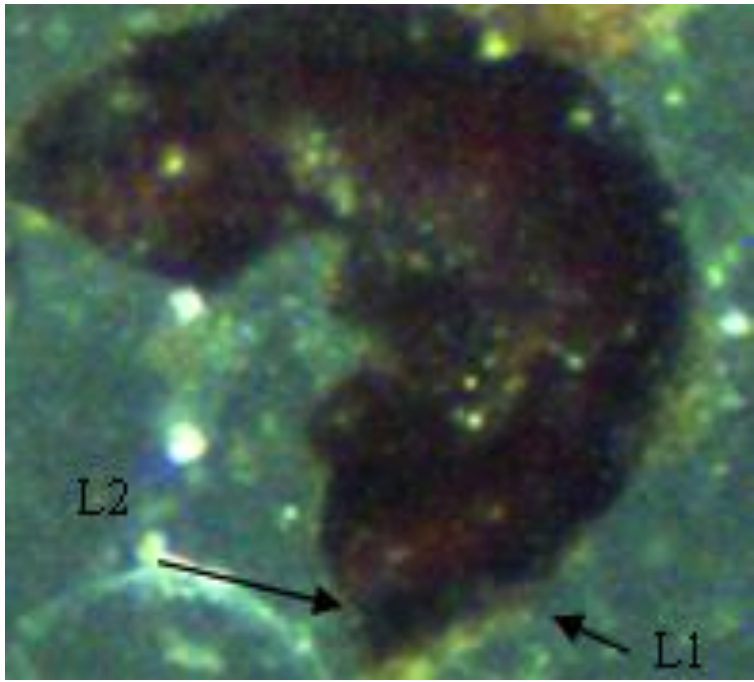

A2

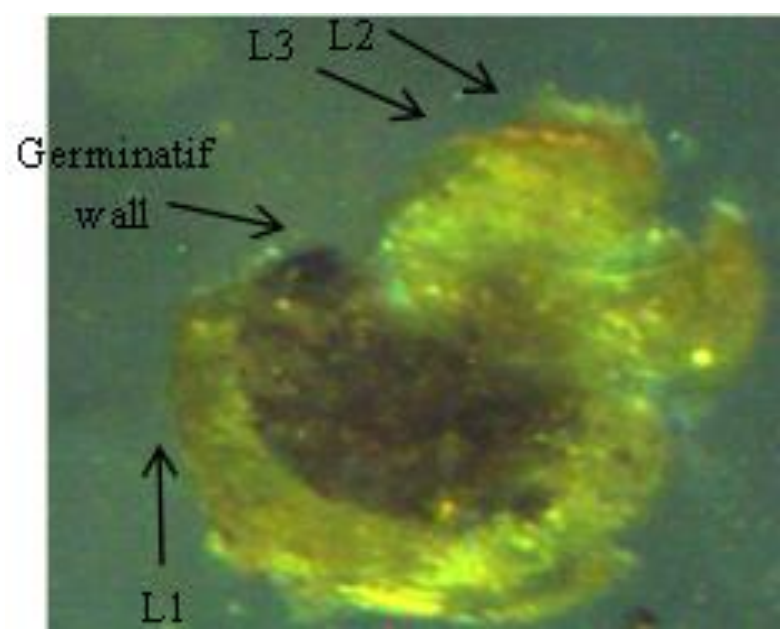

B2

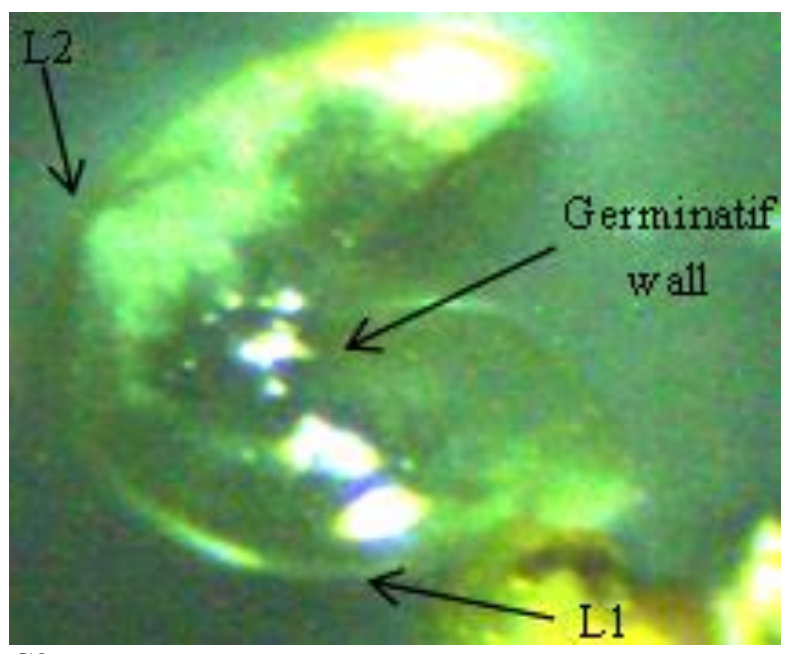

$\mathrm{C} 2$ 
D

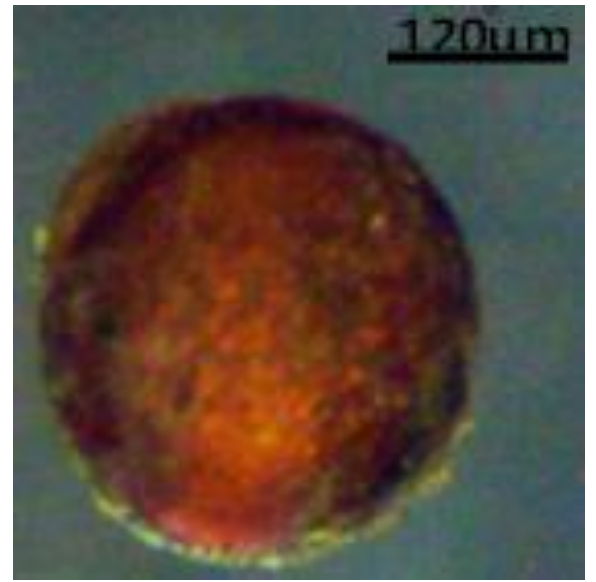

D1

$\mathrm{E}$

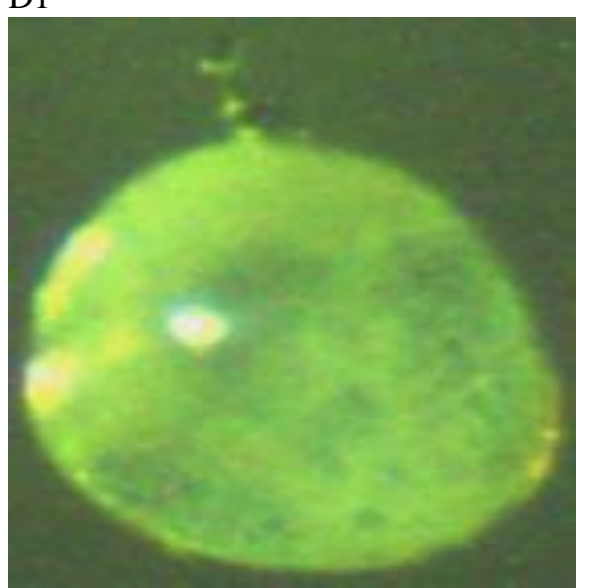

E1

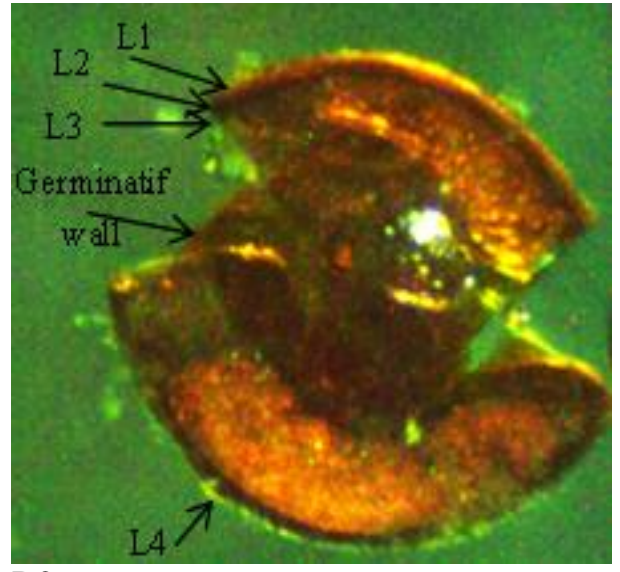

D2

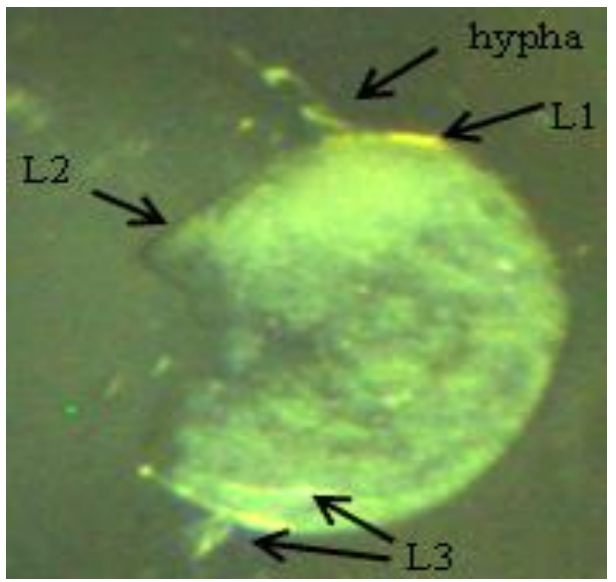

E2

Figure 6 : Morphological and structural diversity of isolated spores.

A : Glomus constrictum ; B : Glomus manihotis ; C : Acaulospora kentinensis ; D : Entrophospora infrequens ; $\mathrm{E}:$ Rhizophagus intraradices.

\section{Conclusion}

In this study, Gossypium hirsutum L. (cotton) was found to be dependent on endomycorrhizal symbiosis in the North Cameroon. Five Arbuscular Mycorrhizal Fungi (AMF) species were involved in this symbiosis in the Mayo-Rey, Benoue and Mayo-Louty Division of North Cameroon which are: Glomus constrictum, Glomus manihotis, Acaulospora kentinensis, Entrophospora infrequens, Rhizophagus intraradices. The strain Glomus constrictum was dominant, while $E$. infrequens was the less frequently encountered specimen. The identification of these endogenous endomycorrhizal spores structures in soils is a potential opportunity for production of endomycorrhizal inoculants to improve cotton productivity in this part of the country. Since, AMF affect not only a single plant species but also populations and plant species composition, these inoculants could be applied to other crop plants.

\section{References}

1. Abakar AS, Megueni C, Tchuenteu TL. \& Kosma P: 2019. Response of two cotton varieties on mycorrizal inoculation at Sudano-Sahelian savannah of Cameroon. East African
Scholars Journal of Agriculture and Life Sciences, 2(3) : 145154.

2. Abbas Y, Ducousso M, Abouroh M, Azcon R. \& Duponnois $\mathrm{R}: 2006$. Diversity of arbuscular mycorrhizal fungi in Tetraclinis articulate (Vahl) Masters Woodlands in Morocco. Annals of Forest Science, $63: 285-291$.

3. Aragão F, Vianna GR, Carvalheira SBRC \& Rech EL : 2005. Germ line genetic transformation in cotton (Gossypium hirsutum L.) by selection of transgenic meristematic cells with a herbicide molecule. Plant Science, 168(5):1227-1233.

4. Azcón-Aguillar C, Palenzuela J, Roldan A, Bautista S, Vallejo R. \& Barea JM: 2003. Analysis of the mycorrhyzal, potential in the rhizosphere of representative plant species from desertification Threatened-Mediterranean shrublands. Applied Soil Ecology, 22: 29-37.

5. Bansal M, Kukreja K. \& Dudeja SS : 2012. Diversity of Arbuscular mycorrhizal fungi, prevalent in rhizosphere of different crops grown in the university farm. African Journal of Microbiology Research, 6(21) : 4565.

6. Barker KR: 1985. Sampling nematode communities. In an advanced Treatise on Meloidogyme, Methodology (vol. 2) Barker R, SASSER J.N. (eds). North Carolina State University Graphics, Raleigh: USA, 3-14.

7. Brundrett M, Bougher N, Dell B. \& Malajczuk N: 1996. Working with mycorrhizas in forestry and agriculture. Australian Center for International Agricultural Research. ACIAR Monograph 32. Canberra, Australia. 374 p. 
8. Shahin A, Bakar A, Md. Abu BS. \& Ara B : 2018. Cotton Seed oil cake as a valuable Source of Plant Nutrients for Sustainable Agriculture. The Pharmaceutical and Chemical Journal, 5(3):39-45.

9. Caravaca F, Barea JM, Figueroa D. \& Roldán A : 2002. Assessing the effectiveness of mycorrhizal inoculation and soil compost addition for enhancing reaforestation with Olea europaea subsp. sylvestris through changes in soil biological and physical parameters. Applied Soil Ecology, 20, 107-118.

10. Cius A : 2017. Appréciation du potentiel mycorhizien des sols d'arboriculture fruitière et de cultures sarclées d'Haïti par l'isolement de souches indigènes de champignons mycorhiziens arbusculaires. Mémoire de fin d'études agronomiques, Université d'Etat d'Haïti, Faculté d'Agronomie et de Médecine Vétérinaire, Département de Phytotechnie, $46 \mathrm{p}$.

11. Dalpé Y : 2003. Subsidiary Body on Scientific Technical and technological Advice (SBTTA). In:Convention sur la biodiversité. Blumwald E. (eds). Macmillan. London, pp. 100-130.

12. Dalpé, Y. 2005. Les mycorhizes : un outil de protection des plantes mais non une panacée. Phytoprotection.86(1): 53-59.

13. Dechamplain N. \& Gosselin L: 2002. Les champignons mycorhiziens. Université Laval/Québec.

14. Diouf D, Fall D, Kane A, Bakhoum N, Ba AT,Ba A. \& Duponnois R: 2013. Effet de l'inoculation avec des souches de Mesorhizobium sp. et/ou des champignons mycorhiziens a arbuscules sur la croissance et la nutrition minérale de plants d'Acacia seyal Del. Institut de recherche pour le développement Marseille, IRD éditions 2013. pp. 231261.

15. Guibert H, Fesneau C. \& M'Biandoun M : 2008. Variations in soil fertility under cotton crops in the Bénoué cottongrowing area in Northern Cameroon. In : Beltwide Cotton Conferences, Nashville, Tennessee, January 8-11, 2008. National Cotton Council of America. Memphis : NCCA, 1635-1641. Beltwide Cotton Conferences, Nashville, ÉtatsUnis.

16. Gemma JN, Koske RE, Roberts EM. \& Hester S : 2011 Response of Taxus times media var. densiformis to inoculation with arbuscular mycorrhizal fungi. Canadian Journal of Forest Research. 28(1):150-153.

17. Haougui A, Souniabe PS, Doumma A. \& Adam T : 2013. Evolution des populations des champignons endomycorhiziens sur les adventices de quatre sites maraîchers de la région de Maradi au Niger. International Journal of Biological and Chemical Sciences, 7(2) :556-557.

18. INRA : 2017. Multiplier des champignons mycorhiziens sur son exploitation, fiche technique $\mathrm{N}^{\circ} 2$, INRA-Centre Inra Antilles-Guyane - ASTRO - Service Communication/GS Édition 2017

19. INVAM : 2018. International Culture Collection of Vesicular Arbuscular Mycorrhizal Fungi, site de West Virginia University http://invam.wvu.edu/fungi/

20. Kadekoy-Tigague D : 2010. Impact des stratégies multifonctionnelles sur la performance économique des exploitations agricoles en zone de savanes de Centrafrique face à la crise cotonnière. Anthropologie sociale et ethnologie. Université Rennes 2 ; Université Européenne de Bretagne,

21. Koske RE. \& Tessier B: 1983. A convenient, permanent slide mounting medium. Newsletter American Mycological Society, 34-59.

22. Mathimaran N, Ruh R, Vullioud P, Frossard E. \& Jansa J : 2005. Glomus intraradices dominates arbuscular mycorrhizal communities in a heavy texture agricultural soil. Mycorhiza, $16: 61-66$.

23. Mbonigaba MJJ, Nzeyimana I, Bucagu C. \& Culot M : 2009. Caractérisation physique, chimique et microbiologique de trois sols acides tropicaux du Rwanda sous jachères naturelles et contraintes à leur productivité. Biotechnology, Agronomy, Society and Environment, 13(4).
24. MINADER : 2013. Brève présentation de la situation du coton camerounais; Campagne 2012/2013, Cameroun.11p.

25. Morton B. \& Benny GL: 1990. Revisedclassification of arbusculars mycorrhizafungi (Zygomycètes): New order Glomales, two new families Acaulosporaceae and Gigasporaceae with an amendation of Glomaceae Mycotaxon, 37, 471-491.

26. Olina BJ-P, M'Biandoun JA, Ekorong \& Asfom P : 2008.Evolution de la fertilité des sols dans un système cotonnier céréales au Nord Cameroun: diagnostic et perspectives. $240 \mathrm{p}$.

27. Phillips JM. \& Hayman DS : 1970. Improved procedures for clearing roots and staining parasitic and vesicular-arbuscular mycorrhizal fungi for rapid assessment of infection. Transaction of the British Mycological Society, 55: 158-160.

28. Pielou EC : 1966. The measurement of diversity in different types of biological collections. Journal of Theoretical Biology, 13, 131-144.

29. Sghir F, Chliyeh M, Kachkouch W, Khouader M, Ouazzani TA, Benkirane R. \& Douira A : 2013. Mycorrhizal status of Olea europaea spp. oleaster in Morocco. Journal of Applied Biosciences, 61, 4478-4489.

30. Shahin A, Bakar A, Md Abu BS. \& Ara B : 2018. Cotton seed oil and cake as valuable source of plant nutirnts for sustainable agriculture. The Pharmaceutical and Chemical Journal, 5(3) : 39-45.

31. Shannon CE: 1948.A mathematical theory for communication. Bell System Technical Journal, 27 379-423 et 623-656.

32. Shukla A, Kumar A, Jha A, Chartuvedi OP, Prasad R. \& Gupta A : 2009. Effects of shade on arbuscular mycorrhizal colonization and growth of croops and tree seedlings in central India. Agroforestry Systems, 109.

33. Sidhoum W : 2011. Diversité des mycorhizes arbusculaires chez la variété « Sigoise » d'olivier (Olea europea $L$.) : étude de leurs efficacités sur la croissance des plantes. Mémoire de Magister en Biotechnologie, Université d'Oran Es-senia, Faculté des Sciences, Département de la Biotechnologie, 99 p.

34. Symanczik S: 2016. Arbuscular mycorrhizal (AM) fungal diversity of arid lands: From AM fungal species to AM fungal communities- $\mathrm{PhD}$ Thesis, University of Basel, Germany, $160 \mathrm{p}$.

35. Tobolbai R, Adamou S. \& Ngakou A : 2018. Morphological and structural of indigenous endomycorrhiza communities associated to maize [Zea mays (L.)] in Northern Cameroonian soils. Journal of Animal \& Plant Sciences, 38(1):6057-6073

36. Trouvelot A, Kough JL \& Gianinazzi-Pearson V : 1986 Mesure du taux de mycorhization VA d'un système radiculaire. Recherche de méthodes d'estimation ayant une signification fonctionnelle. In: physiology and genetics aspects of mycorrhizae. Gianinazi-Pearson $V$ et Gianinazzi $S$ (Eds), 1st ESM, INRA Press, Paris, 217-221 p

37. Tsozue D, Nghonda JP. \& Mekem DL: 2015. crop yields and soil fertility in Cameroon. Journal of solid Earth, $7: 1761$ 1796.

38. Voko Bi DRR, Ahonzo-Niamke SL. \& Zeze A: 2013. Impact des propriétés physicochimiques des sols de culture du manioc sur l'abondance et la diversité des communautés de champignons mycorhiziens à arbuscules dans la zone agroécologique d'Azaguie, sud-est de la côte d'ivoire. Agronomie Africaine 25 (3) : 25-264.

39. Wang B. \& Qiu YL: 2006. Phylogenetic distribution and evolution of mycorrhizas in land plants. Mycorrhiza, 16: 299-363.

40. Zézé A, Ouattara, Brou CY, Van tuinen D, Diallo-attah H. \& Sangare A : 2007. Distribution et abondance de spores de champignons endomycorhizogenes a arbuscules dans différents types de forêts de la Tene en Côte d'Ivoire. p108. Agronomie Africaine, 19 (2) : 103-111. 